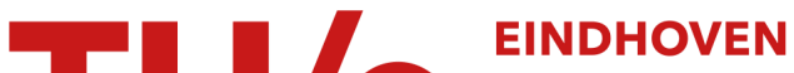 \\ UNIVERSITY OF \\ TECHNOLOGY
}

\section{Supramolecular polymer interactions using melamine}

Citation for published version (APA):

Lange, R. F. M., \& Meijer, E. W. (1996). Supramolecular polymer interactions using melamine. Macromolecular Symposia, 102, 301-308. https://doi.org/10.1002/masy.19961020136

DOI:

10.1002/masy. 19961020136

Document status and date:

Published: 01/01/1996

\section{Document Version:}

Accepted manuscript including changes made at the peer-review stage

\section{Please check the document version of this publication:}

- A submitted manuscript is the version of the article upon submission and before peer-review. There can be important differences between the submitted version and the official published version of record. People interested in the research are advised to contact the author for the final version of the publication, or visit the $\mathrm{DOI}$ to the publisher's website.

- The final author version and the galley proof are versions of the publication after peer review.

- The final published version features the final layout of the paper including the volume, issue and page numbers.

Link to publication

\section{General rights}

Copyright and moral rights for the publications made accessible in the public portal are retained by the authors and/or other copyright owners and it is a condition of accessing publications that users recognise and abide by the legal requirements associated with these rights.

- Users may download and print one copy of any publication from the public portal for the purpose of private study or research.

- You may not further distribute the material or use it for any profit-making activity or commercial gain

- You may freely distribute the URL identifying the publication in the public portal.

If the publication is distributed under the terms of Article $25 \mathrm{fa}$ of the Dutch Copyright Act, indicated by the "Taverne" license above, please follow below link for the End User Agreement:

www.tue.nl/taverne

Take down policy

If you believe that this document breaches copyright please contact us at:

openaccess@tue.nl

providing details and we will investigate your claim. 


\title{
SUPRAMOLECULAR POLYMER INTERACTIONS USING MELAMINE
}

\author{
Ronald F.M. Lange and E.W. Meijer*
}

DSM Research, P.O. Box 18, 6160 MD Geleen, The Netherlands.

\begin{abstract}
Triple-hydrogen bonding between the imide containing polymers 1a-c and melamine 2 is used to obtain supramolecular interactions between macromolecules. Melamine, known as a compound barely soluble in any organic solvent, is molecularly dissolved in the copolymers 1a-c by meltprocessing. Maximum concentrations of 1 equivalent amount of melamine per 2.5 equivalent amounts of copolymer are obtained, indicating a 3:1 mol:mol superstructure with physical crosslinking by hydrogen bonding. Crystalline melamine is detected by powder diffraction X-ray analysis at melamine concentrations exceeding the $3: 1$ imide-melamine mole ratio.
\end{abstract}

\section{INTRODUCTION}

The structure of the supramolecular complex between melamine and cyanuric acid is proposed to be an infinite two-dimensional lattice as is shown in figure 1 (Ref. 1). However, the parent structure is not confirmed by X-ray analysis yet, due to the lack of appropiate crystals. Therefore, only $\mathrm{HCl}$ salts have been studied (Ref. 2) and detailed information on the structureproperty relationship of the parent complex is obtained by model studies. Recently, fascinating

\section{* Present address:}

Laboratory of Organic Chemistry, Eindhoven University of Technology, P.O. Box 513, 5600 MB Eindhoven, The Netherlands. 


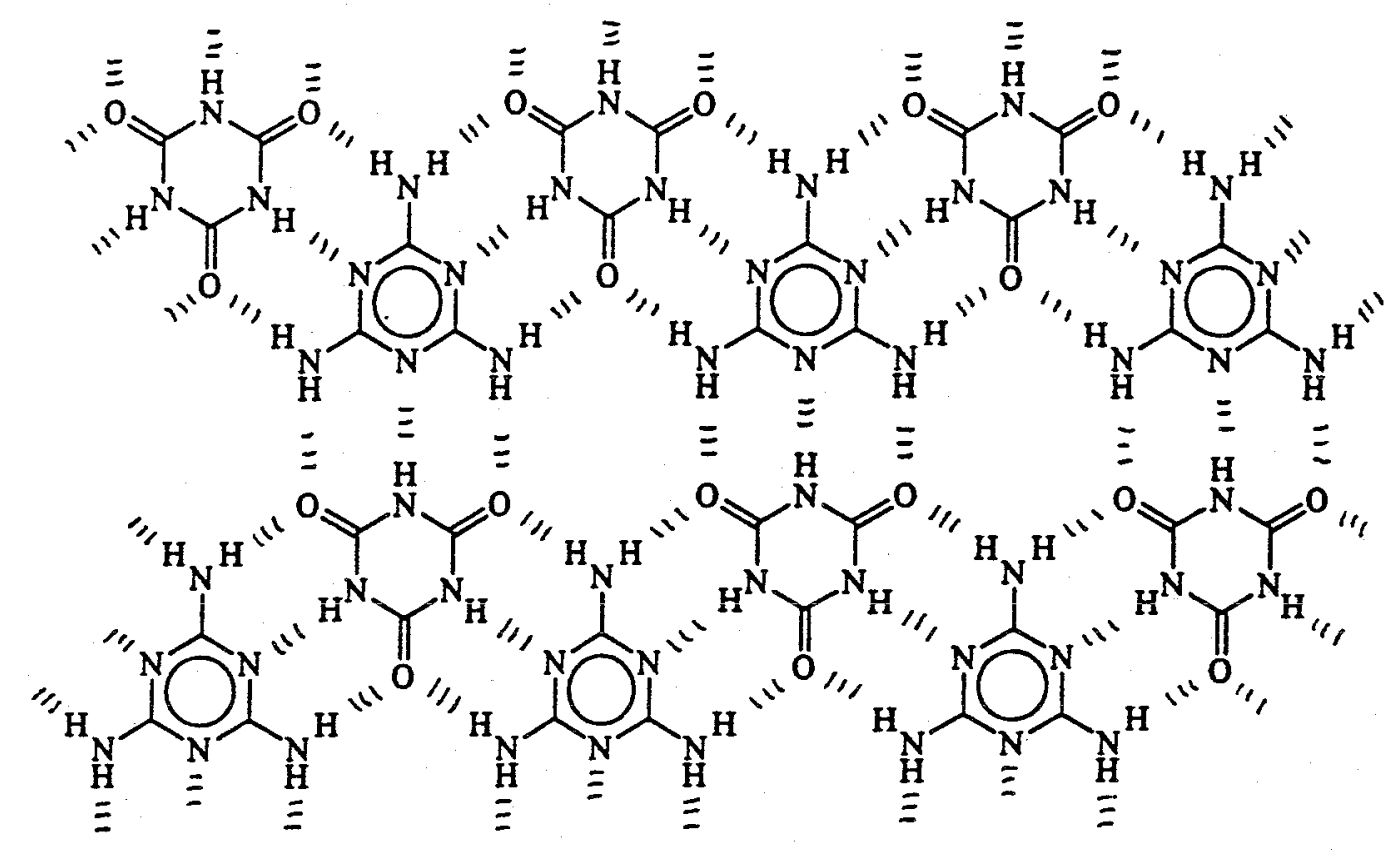

Fig. 1. Proposed infinite two-dimensional melamine-cyanuric lattice

results have been reported by Lehn et al. and Whitesides et al. (Ref. 3) in which it is shown that well-defined supramolecular complexes can be obtained by designing appropiate complementary couples based on triple-hydrogen bonding. Despite the importance of macromolecules in natural systems, research in the field of supramolecular chemistry using melamine and melamine-type structures is mainly focused on low molecular weight molecules. The use of secondary interactions in the formation of polymer blends is a well-accepted strategy; donor-acceptor complexes (Ref. 4), ion pairs (Ref. 5) and hydrogen bonding (Ref. 6) represent some successful examples. Self-assembly of macromolecules is investigated in detail for liquid crystallinity, hydrophobic interactions, hydrogen bonding interactions, amphiphilic structures and rotaxanes (Ref. 7). Recently we reported on the results of the supramolecular interactions between the alternating copolymer of styrene and maleimide, 1a, with melamine, 2 , and of $\mathbf{1 a}$ with the random copolymer of styrene and 2,4-diamino-6-vinyl1,3,5-triazine (Ref. 8). In this paper we will extend this study with the supramolecular interactions of melamine with the alternating copolymer of 4-methylstyrene and maleimide, $1 \mathrm{~b}$, and of melamine with a random copolymer of styrene and maleimide containing $28 \mathrm{~mol} \%$ of maleimide, 1c, aiming at a detailed insight into the structure-property relationship of these molecularly dissolved polymer blends. The interactions between 1a-c with 2 are based on the concept of triple-hydrogen bonding as is shown in figure 2 . 


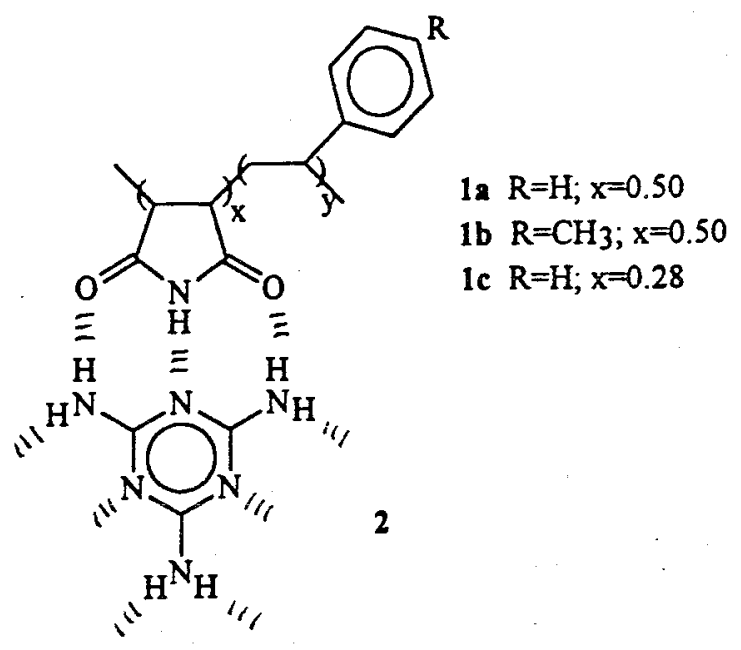

Fig. 2. Triple-hydrogen bonding interactions between $1 \mathrm{a}-\mathrm{c}$ and 2

\section{RESULTS AND DISCUSSION}

In order to study multiple hydrogen bonding of melamine and imide containing polymers, the copolymers 1a-c are synthesized, and commercially available 2 is used. The alternating, atactic copolymers $1 \mathrm{a}$ and $\mathbf{1 b}$ are obtained by a radical polymerization of styrene, 1a, or 4methylstyrene, $\mathbf{1 b}$, with maleimide at $60^{\circ} \mathrm{C}$, using AIBN as initiator (Ref. 9). DEPT ${ }^{13} \mathrm{C}-\mathrm{NMR}$ spectroscopy (Ref. 10) as well as elemental analysis of $1 \mathbf{a}$ and $1 \mathbf{b}$ reveal that alternation over $95 \%$ is obtained. Copolymer 1a possesses a glass transition temperature ( $\mathrm{Tg}$ ) of $250^{\circ} \mathrm{C}$. The molecular weight $(\mathrm{Mn})$ is $77.10^{3} \mathrm{~g} \cdot \mathrm{mol}^{-1}$ whereas the molecular weight distribution $(\mathrm{Mw} / \mathrm{Mn})$ is 2.1 (Ref. 11). Copolymer $1 \mathrm{~b}$ possesses a Tg of $246^{\circ} \mathrm{C}$ and a $\mathrm{Mn}$ of $3.9 .10^{3} \mathrm{~g} \cdot \mathrm{mol}^{-1}$ whereas the molecular weight distribution is 6 . Copolymer $1 \mathrm{c}$ is prepared by the imidization of the corresponding anhydride copolymer using urea (Ref. 12) and possesses a $\mathrm{Tg}$ of $192^{\circ} \mathrm{C}$. The $\mathrm{Mn}$ is $46.10^{3} \mathrm{~g} \cdot \mathrm{mol}^{-1}$ whereas the molecular weight distribution is 2.2 .

Blending the imide copolymers 1a-c with various amounts of 2 is carried out in the melt using an extruder, as previously reported (Ref. 8). The dependence of the $\mathrm{Tg}$ on the concentration of melamine is given in figure 3 for the blend of 12 with 2 . Addition of melamine results in a dramatic decrease of the $\mathrm{Tg}$, up to melamine concentrations of $20 \%$ (w/w), at which it levels off at around $215^{\circ} \mathrm{C}$. In order to get more insight into the state of mixing of 1a with 2 , powder diffraction X-ray analysis of the prepared samples has been performed. Reflections 


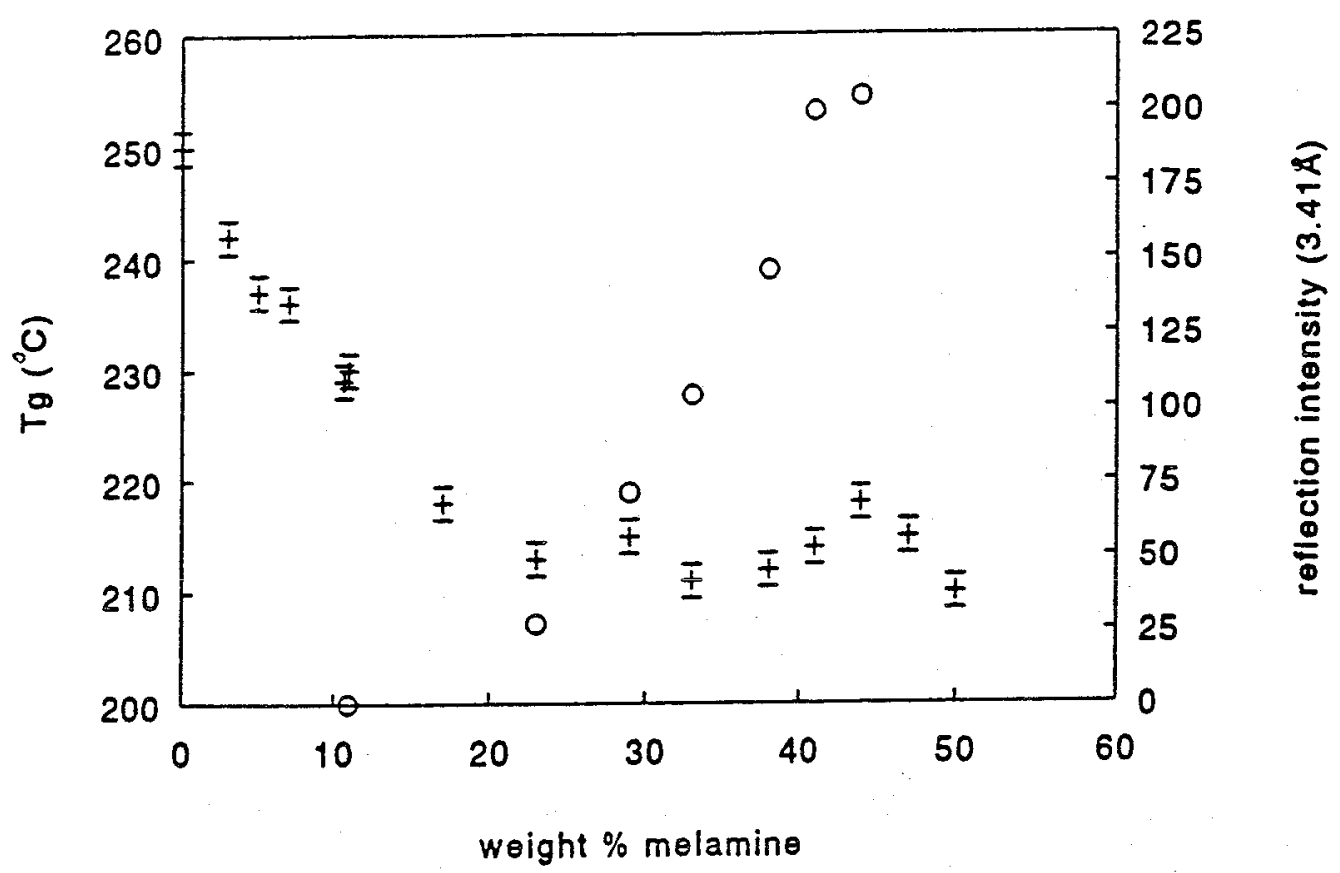

Fig. 3. Dependence of $\operatorname{Tg}( \pm)$ and melamine reflection intensity ( $O$ ) on the concentration of melamine in the blend of $1 \mathrm{a}$ with melamine. Extrapolation of the intensity of reflection to zero results in $20.2 \%(\mathrm{w} / \mathrm{w})$ melamine.

at $3.41 \AA(\mathrm{Cu} / \mathrm{K} \alpha$ radiation) for crystalline, undissolved, melamine are detected only at melamine concentrations of $23 \%(\mathrm{w} / \mathrm{w})$ and higher (Ref. 13). Extrapolation of the intensity of reflection to zero (Ref. 14) shows that no melamine crystals are present at a concentration lower than $20.2 \%(\mathrm{w} / \mathrm{w})$ of melamine, as is shown in figure 3 . This corresponds to an imide:meiamine ratio of $2.5: 1$. The figure shows as well, that this point coincides with the onset of $\mathrm{Tg}$ stabilization. Therefore, it is concluded that melamine, known as a compound barely soluble in any organic solvent, is molecularly dissolved in 1 up to an imide : melamine ratio of $2.5: 1$. Hence, it is proposed that one melamine molecule interacts with three imide units of the polymer, leading to a three dimensional hydrogen bonded polymer network, hereby disrupting the imide-imide interaction.

In order to study the structure-property relationship of this triple-hydrogen bonded interaction of melamine with imide-containing polymers, we have blended $\mathbf{1 b}$ and $1 \mathrm{c}$ with various amounts of 2 . The results are depicted in the figures 4 and 5 . From figure 4 it is seen that the results obtained by using $1 \mathrm{~b}$ are comparable with the blend of $1 \mathrm{a}$ and melamine. Here too, a dramatic decrease in $\mathrm{Tg}$ is observed up to the 3:1 imide-melamine ratio (theoretically $16.3 \%(w / w))$ at which it levels off at around $220^{\circ} \mathrm{C}$. Extrapolation of the intensity to zero 


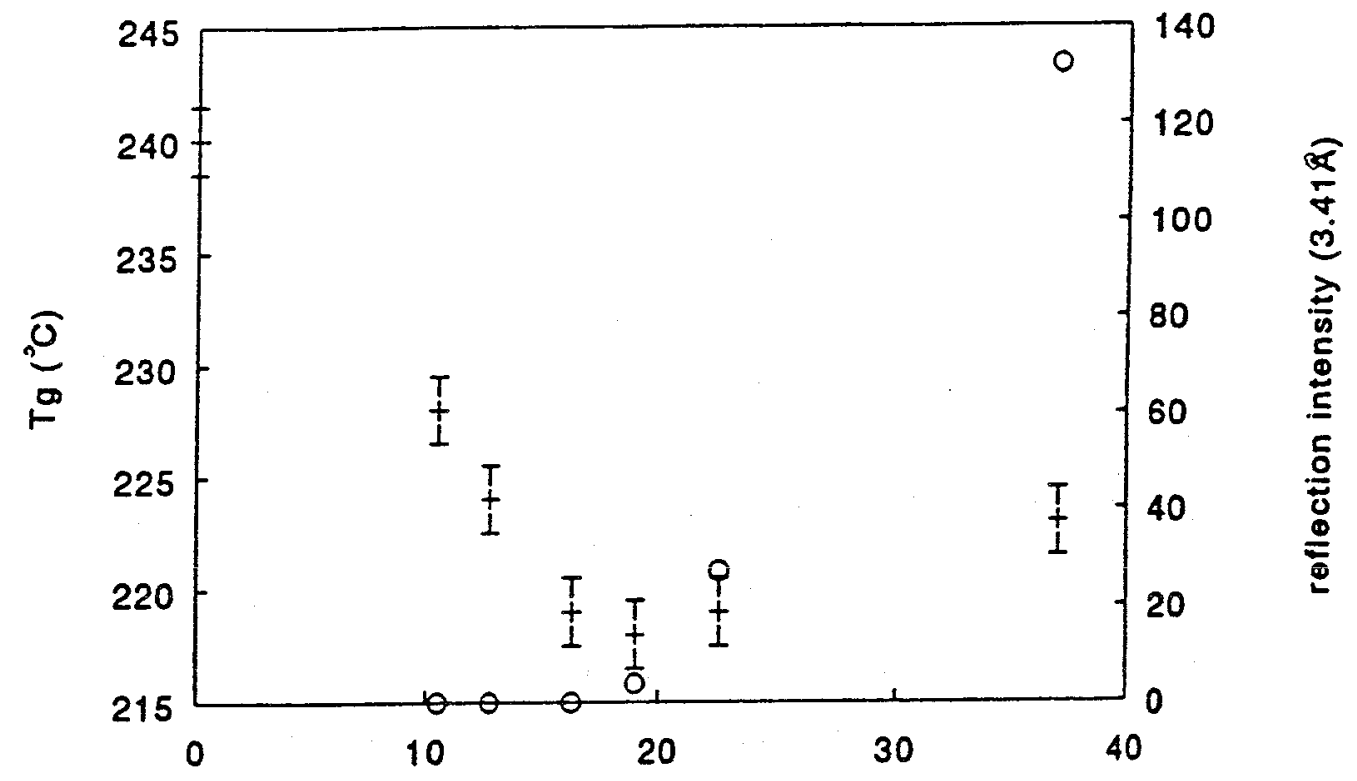

weight $\%$ mslamine

Fig. 4. Dependence of $\operatorname{Tg}( \pm)$ and melamine reflection intensity ( $O$ ) on the concentration of melamine in the blend of $1 \mathrm{~b}$ with melamine. Extrapolation of the intensity of reflection to zero results in $18.6 \%(\mathrm{w} / \mathrm{w})$ melamine.

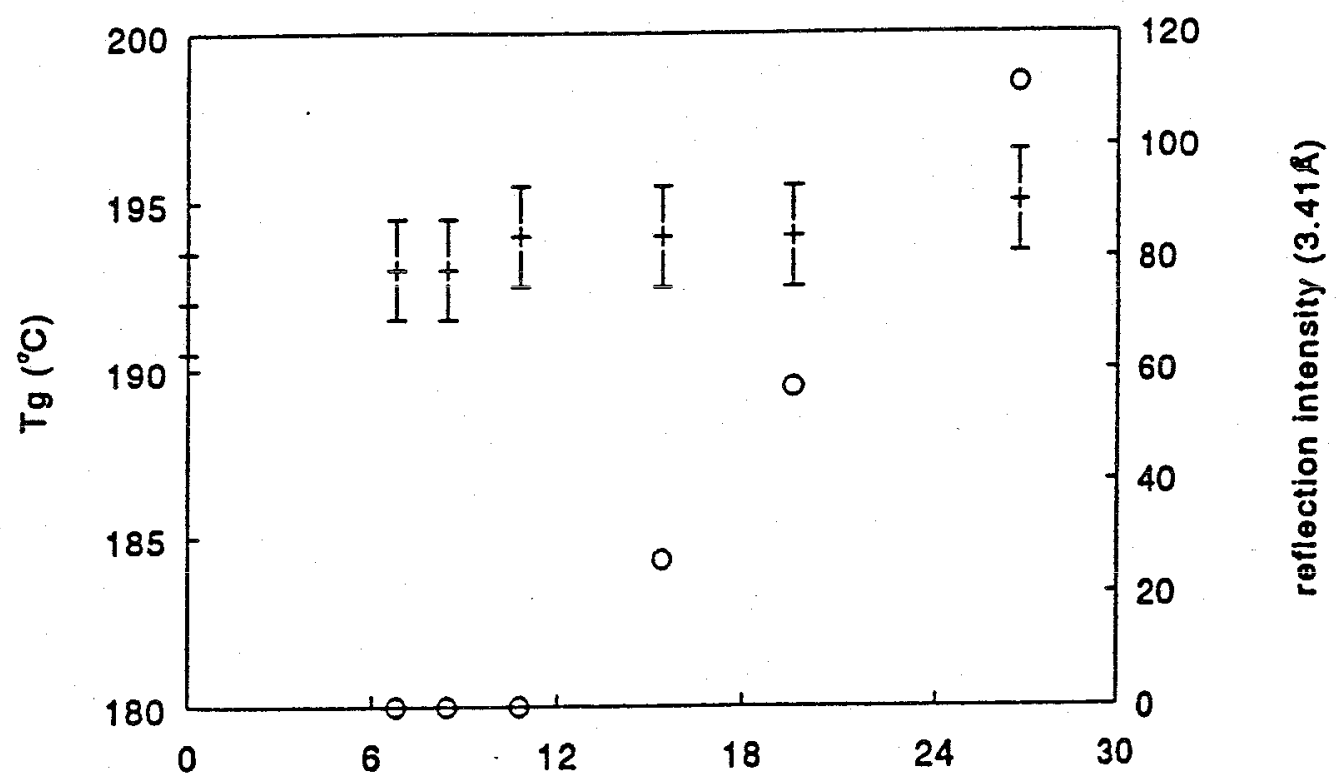

weight $\%$ melamine

Fig. 5. Dependence of $\operatorname{Tg}(\mp)$ and melamine reflection intensity ( $O$ ) on the concentration of melamine in the blend of $1 \mathrm{c}$ with melamine. Extrapolation of the intensity of reflection to zero results in $12.0 \%(\mathrm{w} / \mathrm{w})$ melamine. 
shows that no melamine crystals are present at concentrations lower than $18.6 \%(\mathrm{w} / \mathrm{w})$ of melamine. This value corresponds to an imide melamine mole ratio of $2.5: 1$, which is in perfect agreement with the blend of $\mathbf{1 a}$ and melamine. Thus, introducing a methyl group on the para position of the styrene unit does not prevent the formation of the proposed 3:1 imidemelamine complex. To investigate the influence of the imide content, copolymer 1c, which contains $28 \mathrm{~mol} \%$ maleimide, is used. Blending $1 \mathrm{c}$ with various amounts of melamine results, like the 1a and 1b melamine blends, to the proposed 3:1 imide melamine complex as is shown in figure 5. A linear relation between the melamine reflection intensity and the melamine concentration is obtained. Extrapolation of the melamine intensity to zero shows that no melamine crystals are present at concentrations lower than $12.0 \%(\mathrm{w} / \mathrm{w})$. This value corresponds to an imide melamine mole ratio of 2.5:1. Surprisingly, this is in agreement with the blends of $1 \mathbf{a}$ and $\mathbf{1 b}$ with melamine. Hence, a decrease in imide concentration and an increase in chain flexibility does not lead to an increase in the maximum concentration of molecularly dissolved melamine. Furthermore, no decrease in $\mathrm{Tg}$ is observed for this 1cmelamine blend. Investigations to explain the "Tg behaviour" and the exact nature of the complex are in progress.

The maximum imide-melamine mole ratios of $2.5: 1$, as found for all three systems studied, are indicative for some kind of supramolecular crosslinking in which three imide units are linked together by one melamine molecule using multiple-hydrogen bonds. Only a cooperative effect is thought to be responsible for dissolving melamine molecularly by the copolymers.

\section{CONCLUSIONS}

The characterization of all the blend compositions of 1a-c with 2 show that multiple hydrogen bonding can give rise to high compatibility. The polymer blends obtained, however, are all amorphous, without showing distinct topologies. Longe-range cooperativity is expected as soon as well-defined stereoregular polymers are used. Future research will be focused on material properties and on the supramolecular architecture with more stereoregular polymers. 


\section{ACKNOWLEDGEMENT}

The authors like to acknowledge the fruitful discussions with and experimental support of many colleagues at DSM Research.

\section{REFERENCES}

(1) A. I. Finkel'shtein, O. S. Rukevich, Zh. Prikl. Specktrosk. 38, 327 (1983) For some background in supramolecular chemistry, see: a) J.-M. Lehn, Angew.Chem. 100, 91 (1988). b) D. Cram, Angew.Chem. 100, 1041 (1988). c) Q. Feng, T. K. Park, J. Rebek, Science, 256, 1179 (1992). d) D. B. Amabilino, P. R. Ashton, C. L. Brown, E. Córdova, L. A. Godínez, T. T. Goodnow, A. E. Kaifer, S. P. Newton, M. Pietraszkiewicz, D. Philp, F. M. Raymo, A. S. Reder, M. T. Rutland, A. M. Z. Slawin, N. Spencer, J. F. Stoddart, D. J. Williams, J.Am.Chem.Soc, 117, 1271 (1995). e) J. Lindsey, New J.Chem. 15, 153 (1991). f) E. Fan, J. Yang, S. J. Geib, C. Vincent, F. Garcia-Tellado, P. Tecilla, A. D. Hamilton, Macromol.Symp. 77, 209 (1994). g) G. M. Whitesides, J. P. Mathias, C. T. Seto, Science 254, 1312 (1991).

(2) Y. Wang, B. Wei, Q. Wang, J. Crystallogr. Spectrosc. Res. 20, 79 (1990)

(3) a) J.-M. Lehn, M. Mascal, A. DeCain, J. Fischer, J. Chem. Soc., Chem. Commun., 479 (1990). b) J. A. Zerkowski, J. C. MacDonald, C. T. Seto, D. A. Wierda, G. M. Whitesides, J. Am. Chem. Soc. 116, 2382 (1994). c) J. A. Zerkowski, G. M. Whitesides, J. Am. Chem. Soc. 116, 4298 (1994). d) J. A. Zerkowski, J. P. Mathias, G. M. Whitesides, J. Am. Chem. Soc. 116, 4305 (1994). e) J. P. Mathias, E. E. Simanek, J. A. Zerkowski, C. T. Seto, G. M. Whitesides, J. Am. Chem. Soc. 116, 4316 (1994). f) J. P. Mathias, E. E. Simanek, G. M. Whitesides, J. Am. Chem. Soc. 116, 4326 (1994).

(4) a) J. M. Rodriguez-Parada, V. Percec, Macromolecules 19, 55 (1986). b) C. Pugh, V. Percec, Macromolecules 19, 65 (1986). c) J. M. Rodriguez-Parada, V. Percec, J. Polym. Sci., Polym. Chem. Ed. 24, 579 (1986). d) C. Pugh, J. M. Rodriguez-Parada, V. Percec, J. Polym. Sci., Polym. Chem. Ed. 24, 747 (1986). e) V. Percec, H. G. Schild, J. M. Rodriguez-Parada, C. Pugh, J. Polym. Sci., Polym. Chem. Ed. 26, 935 (1988).

(5) A. Eisenberg, J. Hara, Polym. Eng. Sci., 22, 307 (1984). 
(6) a) M. M. Coleman, J. F. Graf, P. C. Painter, "Specific Interactions and the Miscibility of Polymer Blends", Technomic Publ. Inc., Lancaster, 1991. b) E. M. Pearce, T. K. Kwei, B. Y. Min, J. Macromol. Sci., Chem. A. 21, 1121 (1984). c) T. K. Kwei, J. Polym. Sci., Polym. Lett. Ed. 22, 307 (1984).

(7) a) H. Ringsdorf, F. Schlarb, G. Venzmer, Angew. Chem. 100, 117 (1988). b) V. Percec, J. Heck, G. Johansson, D. Tomazos, M. Kawasumi, G. Ungar, J. Macrom. Sci., Pure Appl. Chem. A31, 1031 (1994). c) G. Wegner, Mol. Cryst. Liq. Cryst. 235, 1 (1993). d) H. W. Gibson, H. Marand, Adv. Mat., 5, 11 (1993). e) T. Kato, H. Kihara, T. Uryu, A. Fujishima, J. M. J. Fréchet, Macromolecules 25, 6836 (1992). f) T. Kato, H. Kihara, U. Kumar, A. Fujishima, T. Uryu, J. M. J. Fréchet, Polym. Prepr. (Am. Chem. Soc., Div. Polym. Chem.) 34(2), 722 (1993). g) U. Kumar, T. Kato, J. M. J. Fréchet, J. Am. Chem. Soc., 114, 6630 (1992). h) T. Kato, M. Fukumasa, J. M. J. Fréchet, Chem. Mat., 7, 368 (1995). i) C. Hilger, M. Dräger, R. Stadler, Macromolecules 25, 2498 (1992). j) C. Hilger, R. Stadler, Macromolecules, 25, 6670 (1992). k) V. Abetz, C. Hilger, R. Stadler, Makromol. Chem. Macromol. Symp. 52, 131 (1991). 1) J. Hellmann, C. Hilger, R. Stadler, Pol. for Adv. Techn., 5, 763 (1994).

(8) R. F. M. Lange, E. W. Meijer, Macromolecules 28, 782 (1995).

(9) G. van Paesschen, D. Timmerman, Makromol. Chem., 78, 112 (1964).

(10) P. F. Barron, D. J. T. Hill, J. H. O'Donnel, P. W. O'Sullivan Macromol., 17, 1967 (1984).

(11) The molecular weights and the molecular weight distributions are determined by GPC, Ultrastyragel, $\mathrm{THF}+10 \% \mathrm{CH}_{3} \mathrm{COOH}$ and polystyrene as standard̊s.

(12) P. O. Tawney, R. H. Snyder, R. P. Conger, K. A. Leibbrand, C. H. Stiteler, A. R. Williams, J.Org.Chem., 26, 15 (1961).

(13) No reflections at $3.19 \AA$ and $3.26 \AA$ for condensated melamine products could be determined.

(14) The experimental data, except the data point at $41 \%(\mathrm{w} / \mathrm{w})$ melamine (which is obviously an artefact), are fitted using Slidewrite 5.00 (Ref. 13). 